\title{
Estimating age composition in Alpine native populations of Austropotamobius pallipes complex
}

\author{
Daniela GHIA, Gianluca FEA, Aurora CONTI, Roberto SACCHI, Pietro Angelo NARDI \\ Dipartimento di Scienze della Terra e dell'Ambiente, Università degli Studi di Pavia, Via Taramelli 24, 27100 Pavia, Italy \\ *Corresponding author: daniela.ghia@unipv.it
}

\begin{abstract}
Assessing the population structure and understanding growth patterns is crucial to manage freshwater resources and to solve fundamental questions concerning endangered species conservation. Austropotamobius pallipes (Lereboullet, 1858) species complex has been declining on a widespread basis in Europe, including Italy, but detailed data on population structure and growth are lacking. In four low order streams populated by the species, water temperature data were collected by data-loggers. In July 2012, a total of 746 crayfish were collected at night and their length was measured. Females and males size distributions were analysed separately for each stream using Bhattacharya's Method. Age was assigned to each length class. The mean values of the age classes were used to evaluate the growth rate of Von Bertalanffy, by the seasonalized equation. Up to six age classes were identified in two populations. Results show that three out of four populations are well-structured, and they confirm that A. pallipes complex is a K-selected species. We stress the need for long-term monitoring and the importance of obtained results in development of conservation plans of endangered crayfish.
\end{abstract}

Key words: Population structure, freshwater crayfish, Von Bertalanffy parameters, growth model, water temperature.

Received: November 2014. Accepted: March 2015.

\section{INTRODUCTION}

The populations of the freshwater crayfish Austropotamobius pallipes (Lereboullet, 1858) species complex have undergone a remarkable contraction and decline on a widespread basis in Europe (Holdich, 2002; SoutyGrosset et al., 2006; Holdich et al., 2009), including Italy (Aquiloni et al., 2010). This decline is due to causes frequently linked to direct human action, such as habitat fragmentation, deforestation and water deterioration (Nardi et al., 2005; Trouilhe et al., 2007; Favaro et al., 2010). Consequently, the species is listed in the EU Directive 92/43/EEC, commonly known as Habitat Directive (Annex II and V) and it is also listed as endangered by the IUCN (Füreder et al., 2010). Moreover, the cause of disappearance of many freshwater crayfish populations is linked (Gherardi and Holdich, 1999; Gherardi et al., 2002) to the introduction of non-indigenous species, such as Procambarus clarkii (Girard, 1852) and Orconectes limosus (Rafinesque, 1817), carriers of the oomycete Aphanomyces astaci Schikora 1906, the crayfish plague (Aquiloni et al., 2011). Recent studies in its native habitat showed that $P$. clarkii has distinct ecological requirements with respect to A. pallipes (Dorr and Scalici, 2013) and the propagule pressure drives the colonization success of invasive freshwater crayfish (Capinha et al., 2013). Therefore, suitable management strategies should be planned to prevent the extinction of native crayfish populations (Manenti et al., 2014). Actually, some management proj- ects have been undertaken to conserve threatened populations of native crayfish in several European countries (Bernardo et al., 1997; Dieguez-Uribeondo et al., 1997; Holdich and Rogers, 1997; Whitehouse et al., 2009; Piccoli et al., 2012; Berger and Füreder, 2013); but detailed knowledge of growth dynamic of the species is important for the definition of conservation actions and management plans (Grandjean et al., 1997a). Studies of population dynamics can have a useful role in reintroduction programmes (Scalici et al., 2008). Therefore understanding of the growth rate of a population can help to predict the colonisation rate of a re-stocked waterbody, the minimum number of individuals of selected ages to reliably establish a new population, and the time required before it is likely to be detected by various survey methods. According to the Habitat Directive, EU member states are obliged to maintain the protected species at or restore them to a favourable conservation status (FCS). One of the first steps for assessing the FCS is the understanding of population dynamics, which must indicate good chances for long-term species survival in its natural habitats (Mehtälä and Vuorisalo, 2007).

Previous studies demonstrated a high variability in growth parameters of $A$. pallipes complex (Lowery, 1988) and growth rate affected by latitude (Vogt, 2012) showing that the former increases with a decrease of the latter (Scalici et al., 2008). Generally the growth rate of crayfish is slow at low temperature, so growth slows or ceases in winter. In oceanic or continental climates in higher lati- 
tudes or at higher altitude, crayfish grow more slowly than in areas characterised by Mediterranean climate (Scalici et al., 2008). Hence crayfish in streams in northern Italy at the edge of the Alpine region are likely to grow more slowly than those in low-lying areas of central and southern Italy.

This study aimed to assess the population structure, growth and mortality rates of the white-clawed crayfish A. pallipes complex in northern Italy by applying fish stock assessment principles. The lack of stable skeletal structures, e.g. the growth rings on scales of fish (Hartnoll, 2001), complicates the estimation of age, growth and mortality in all crustaceans (France et al., 1991). The use of size-frequency distributions to distinguish among modal size groups in order to estimate the rate of growth is a long established method in aquatic sciences (Quinn and Deriso,
1999; Smietana and Krzywosz, 2006) as body length distributions within populations are quite easy to recover.

\section{METHODS}

\section{Study area}

The study was carried out in four high-gradient streams belonging to the Po river basin, in the southern part of the Alpine biogeographic region (Fig. 1). Each studied stream has a population of white-clawed crayfish A. pallipes complex. These sites are located in the altitudinal range typical for $A$. pallipes complex in Lombardy (Fea et al., 2006; Piccoli et al., 2012) and their values of annual mean water temperature are similar (Tab. 1) and optimal for the species (Souty-Grosset et al., 2006). Moreover, the studied streams are chosen within European pro-

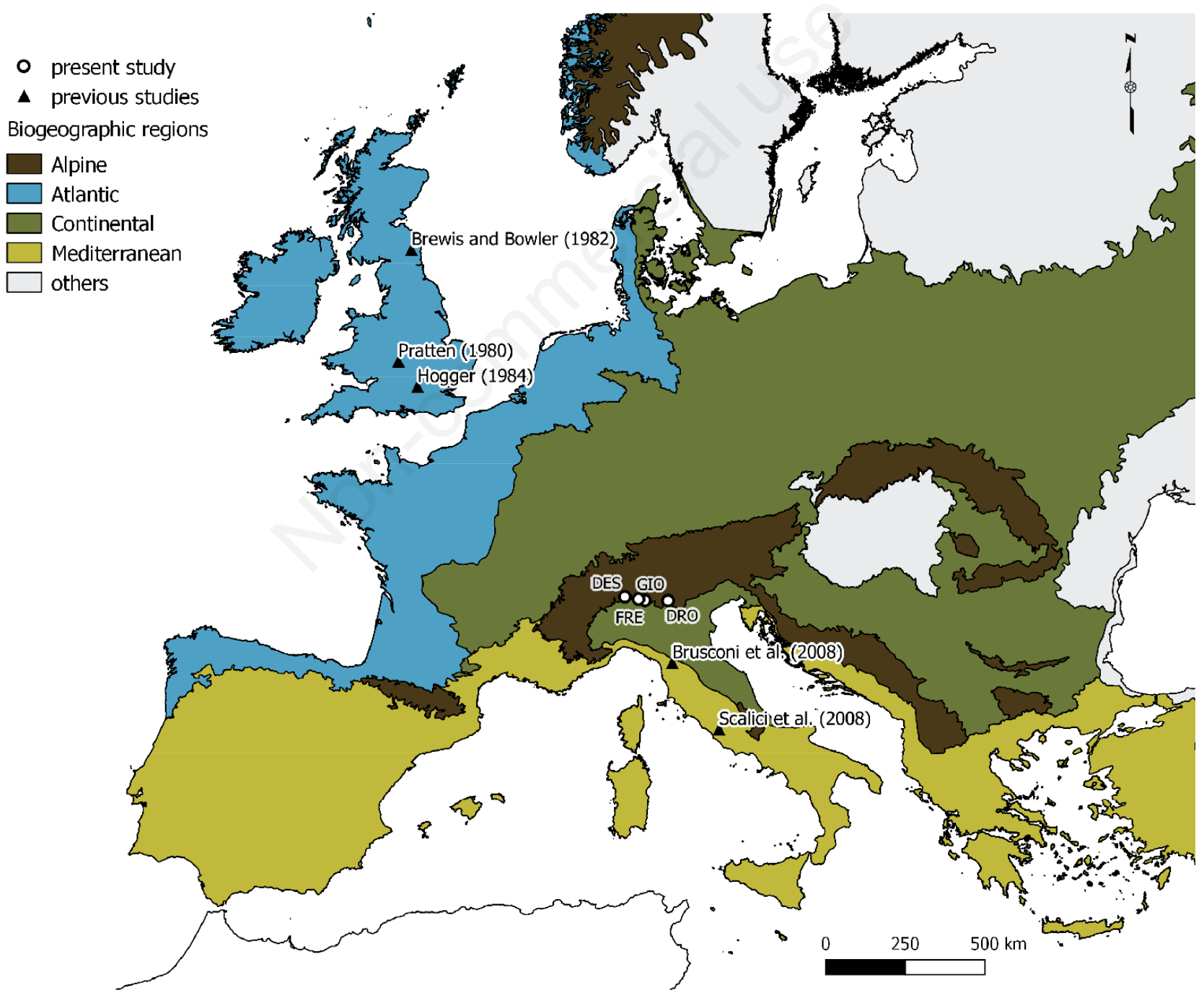

Fig. 1. Streams of the present study and localities of previous studies in the contest of the EU biogeographical regions (http://www.eea.europa.eu/data-and-maps/data/biogeographical-regions-europe). 
tected sites (Natura 2000), surrounded by woodland in order that anthropic disturbance as well as poaching actions on the crayfish populations can be considered minimised or null.

At each site a $100 \mathrm{~m}$ stretch representative of stream features was selected, following the Rapid Bioassessment Protocol (Barbour et al., 1999). A standard length of 100 $\mathrm{m}$ can be used to obtain a representative sample of stream, because it includes an adequate mixture of habitats suitable for benthic macroinvertebrates (Barbour et al., 1999).

\section{Data collection}

In each stream the water temperature was recorded during a period of 16 months using Tinytag ${ }^{\circledR}$ temperature loggers (Gemini Data Loggers, UK Ltd., Chichester, UK) at $2 \mathrm{~h}$ intervals (Tab. 1). Crayfish were caught in each stream during 19-24 July 2012 within stable low flow (range from 0.0005 to $0.0616 \mathrm{~m}^{3} \mathrm{sec}^{-1}$ ). Crayfish were caught at night by hand by a suitable number of experts (from one to three, fit for the width of the streams) using torches and walking upstream in order to collect as many crayfish as possible (France et al., 1991; Smith et al., 1996). Crayfish were sexed and sized considering cephalothorax length (CL, from the tip of the rostrum to the posterior median edge of the cephalothorax), using digital calipers (accuracy $\pm 0.1 \mathrm{~mm})$. Wet weight $( \pm 0.1 \mathrm{~g}$ ) was determined using handy spring balances and occurrence of mutilations was also recorded as well as absence or malformation of the rostrum. At the end of each night sampling, all crayfish were released at the collection area.

Because the hatching period had just ended (only a female with larvae was collected), we did not find the young-of-the-year (YOY) during night sampling due to their low movement capability (Gherardi, 2002) and their elusive behaviour (Brusconi et al., 2008). Therefore in order to fill this gap, daily samplings were conducted by turning cobbles to find and measure the YOY.

\section{Data analyses}

For each night crayfish sampling, we calculated catch per unit effort (CPUE, i.e., the number of crayfish divided by the sampling effort, crayfish $\cdot \min ^{-1} \cdot$ expert $^{-1}$; Quinn and Deriso, 1999), density (crayfish $\cdot \mathrm{m}^{-2}$ ) and biomass (total weight of the captured crayfish divided by the area of each stretch, $\mathrm{g} \cdot \mathrm{m}^{-2}$ ). Frequency data were analysed separately for females and males. Because CL is a more reliable measurement due to rigid structure of cephalothorax in contrast to the flexible abdominal joint (Pratten, 1980), only the CL measurements were used to generate histograms of polymodal frequency distributions, using 1 mm CL intervals (Scalici et al., 2008). However, all crayfish without rostrum or with malformation of the rostrum were excluded. Frequency distributions were analysed using Bhattacharya's (1967) Method (BM), included in the FAO-ICLARM Stock Assessment Tools (FiSAT) software (Gayanilo et al., 1996). This procedure enables the decomposition of mixed frequency distributions into their Gaussian components, i.e. the identification in cohorts from a complex distribution of length-frequencies.

The separation of length-frequency samples into their component is an iterative process in that every identified component is subtracted from the remainder of the sample; BM linearizes the normal distributions by computing the natural logarithms of the frequencies. The process is continued until all groups are identified; up to 10 groups can be identified per sampling period. For each Gaussian component the program provides the mean, the standard deviation and the theoretical number of individuals per group, and a separation index value (SI) for two successive groups. Two adjacent Gaussians can be separated when SI $\geq 2$ (Sparre and Venema, 1996). At the end of this analysis, an arbitrary age was assigned to each cohort, so the mean of each Gaussian and the age constitute a set of age classes from which it is possible to derive the growth parameters. In order to ascribe an age to each length class, water temperature data have to be considered as well as degree-days required to birth time and hatching periods (Hartnoll, 2001). Indeed, it is well known that, in temperate waters, the growth of aquatic invertebrates shows strong seasonal oscillations mainly due to fluctuations of temperature and/or food supply (Pauly et al., 1992; Bilgin et al., 2009). In crayfish, after spawning during the incu-

Tab. 1. Climate features of the studied streams (water flow measurements are referred to the crayfish sampling days).

\begin{tabular}{|c|c|c|c|c|c|c|c|}
\hline \multirow[t]{2}{*}{ Stream } & \multirow[t]{2}{*}{ Watershed } & \multirow[t]{2}{*}{$\begin{array}{c}\text { Altitude } \\
\text { (m asl) }\end{array}$} & \multirow{2}{*}{$\begin{array}{c}\text { Annual } \\
\text { mean water } \\
\text { temperature } \\
\left({ }^{\circ} \mathrm{C}\right)\end{array}$} & \multirow{2}{*}{$\begin{array}{c}\text { Range }\left({ }^{\circ} \mathrm{C}\right) \\
\text { (Sept. } 2011 \text { - } \\
\text { Sept. 2012) }\end{array}$} & \multicolumn{2}{|c|}{$\begin{array}{l}\text { Daily mean water } \\
\text { temperature }>10^{\circ} \mathrm{C}\end{array}$} & \multirow[t]{2}{*}{$\begin{array}{l}\text { Water flow } \\
\left(\mathrm{m}^{3} \cdot \sec ^{-1}\right)\end{array}$} \\
\hline & & & & & $\mathbf{N}$ days & mean & \\
\hline Des (DES) & Po - Olona & 564 & 9.6 & $0.6-18.9$ & 173 & 14.1 & 0.0006 \\
\hline Droanello (DRO) & Po - Mincio & 578 & 9.5 & $0.3-17.4$ & 169 & 14.2 & 0.0616 \\
\hline Giongo (GIO) & Po - Adda & 362 & 9.0 & $0.3-19.6$ & 177 & 13.4 & 0.0021 \\
\hline Freddo (FRE) & Po - Adda & 350 & 11.3 & $0.8-21.8$ & 228 & 14.9 & $<0.0005$ \\
\hline
\end{tabular}


bation period the eggs are brooded by the female and the time until hatching is affected by temperature as degree days. Assuming a spawning date of mid-November (according to previous field and laboratory observations by the authors) and considering 1391 CTU (Celsius Temperature Units, degrees $\mathrm{x}$ days; 193 days at mean water temperature of $7.1^{\circ} \mathrm{C} \pm 3.8$ ) according to a study conducted in the same geographic area (Ghia et al., 2011), for each population the date of eggs hatching was computed in regard to water temperature data set (Fig. 2). After determining the date of egg hatching for each population, an age expressed in months was ascribed to each length class. Datasets smaller than about 100 could not discriminate even the number of age components existing in the sample (France et al., 1991), but several studies used successfully smaller datasets when dealing with threatened or endangered species (Bjorndal et al., 1995; Salvidio and Delaugerre, 2003; Brusconi et al., 2008).

The mean values of the age classes were used to evaluate the von Bertalanffy (1938) growth function (VBGF) for each sex by the seasonally oscillating equation (Pauly and Gaschuitz, 1979):

$L(t)=L_{\infty}\left\{1-\exp \left[-k\left(t-t_{0}\right)-(C k / 2 \pi) \sin \left(2 \pi\left(t-t_{s}\right)\right)\right]\right\}$ (eq. 1)

where $L(t)$ is the length at age $t ; L_{\infty}$ is the asymptotic length; $k$ is the growth constant (the rate at which $L_{\infty}$ is reached, i.e., the curvature parameter); $t_{0}$ called the initial condition parameter determines the point in time when the crayfish has zero length (biologically this has no meaning because at hatching the larvae have a certain length); $C$ is the amplitude of the curve (it measures the size of the seasonal variation in growth. When $C=0$, the equation has no seasonal variation and is the same as the von Bertalanffy. The higher the value of $C$, the more pronounced are the seasonal oscillations. When $C=1$ the growth rate becomes zero during the winter or other low growth season); $t_{s}$ is the summer point (the time between $t=0$ and the start of a growth oscillation. It helps to define $t_{s}+0.5=t_{w}$, which expresses the winter point, as a fraction of the year, the period when growth is slowest). Because the only parameter which cannot be estimated directly from the seasonally oscillating growth data is $L_{\infty}$ (Pauly and Gaschuitz, 1979), a preliminary value of $L_{\infty}$ is computed by the relationship proposed by Taylor (1962) and Beverton (1963):

$L_{\infty}=L_{\max } / 0.95$

Moreover, in order to compare the growth parameters resulting from this study to others reported for the whiteclawed crayfish in literature, the growth performance index $\varphi$ ' (Pauly, 1979; Munro and Pauly, 1983) was computed as:

$\varphi^{\prime}=\log k+2 \log L_{\infty}$

This index assumes a nearly constant value within populations of the same species, even if the growth dynamics seem very different. According to Moreau et al. (1986), it supplies a test for the reliability of the growth curves due to a lowest variability of values within popu-

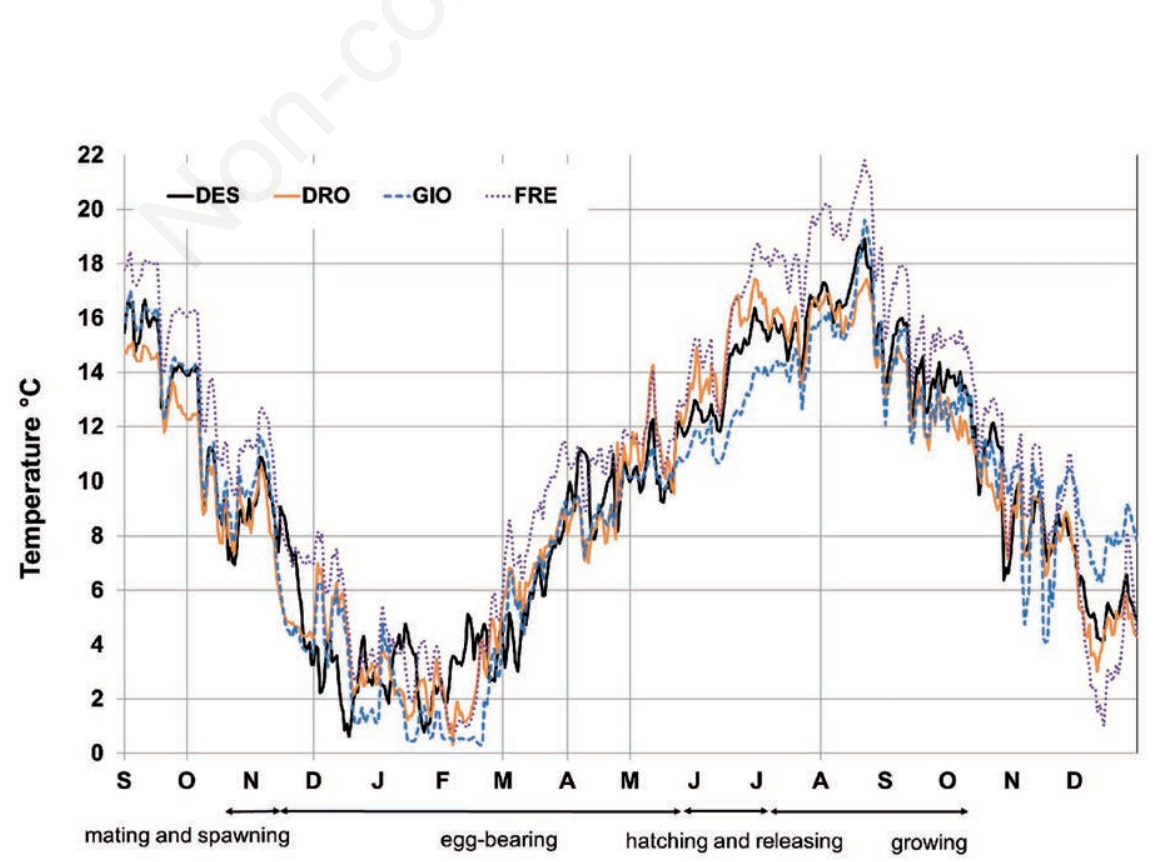

Fig. 2. Water temperature of the study streams over the period $1^{\text {st }}$ September 2011- $31^{\text {st }}$ December 2012. Main phases of $A$. pallipes complex reproduction and grow period are shown. 
lations of the same species. In addition, the total mortality index $(Z)$, i.e. the sum of natural mortality $(M)$ and the mortality due to fishing $(F)$, was obtained using the Powell-Wetherall plot equation (Wetherall, 1986). It calculates the ratio between the mortality coefficient and the curvature parameter $(Z / k)$ using length frequency data.

$M$ was calculated by the following equation (Pauly, 1980):

$\log M=-0.0066-0.276 \log L_{\infty}+0.6543 \log k+0.463 \log T$

where $M$ is the natural mortality, $L_{\infty}$ is the asymptotic length, $k$ is the curvature parameter, and $T$ is the annual mean habitat temperature of the water in which crayfish live. $F$ was obtained subtracting $M$ from $Z$. Finally, the expected longevity $\left(t_{\max }\right)$ was estimated using the following equation:

$t_{\max }=3 / \mathrm{k}+t_{0}$

\section{Statistical analyses}

Frequency data were analysed after using a $\chi^{2}$-test. Von Bertalanffy's parameters were computed using nonlinear regressions. Non-parametric statistical tests were carried out when the scores did not meet the requirements for a normally distributed population (Sokal and Rohlf, 1995). Statistical differences were detected with a level of significance $\mathrm{P}<0.05$ and they were performed with SPSS software (ver. 13.0).

\section{RESULTS}

Overall 746 crayfish (352 males and 394 females) were collected. For each studied stream, the resulting population structure is shown in Tab. 2.

Females were significantly more abundant than males in only one population $\left(\chi^{2}=7.471, \mathrm{df}=1, \mathrm{P}=0.006\right)$, while the sex ratio did not deviate from 1:1 in the remaining three ones. Abundance assessment (CPUE), density and biomass ranged in $0.45-1.37$ crayfish $\cdot \mathrm{min}^{-1}$ expert ${ }^{-1}, 0.72$ 4.48 crayfish $\cdot \mathrm{m}^{-2}$ and $4.39-29.08 \mathrm{~g} \cdot \mathrm{m}^{-2}$ respectively.

Length-frequency distributions obtained using $1 \mathrm{~mm}$
CL interval are shown for each sex and stream (Fig. 3). The BM analysis identified up to six age classes (Tab. 3) in two populations (DES and DRO). The class $0^{+}$was not represented, because only few YOY were caught. Estimating from water temperature data of each stream and from the required degree days, hatching period occurred roughly in late May in FRE stream, in mid-June in DES and DRO, and in late June in GIO (Fig. 4). As these streams, located in the southern part of the Alpine biogeographic region, have similar climatic characteristics (Tab. 1), they have the same effect on the growth rate of the studied populations, thus we assigned the same asymptotic length. Crayfish CL means were pooled, taking into account the shift of hatching periods among streams. So single growth curves for males and females were plotted in Fig. 5. In order to best-fit the curve, in this analysis we considered the CL of the few YOY caught during the daylight. Resulting VB's parameters, details of mortality and growth performance index $\varphi$ ' are given in Tab. 4 and they are compared with data reported in literature in Tab. 5.

After ascribing age to the crayfish according to VB's parameters, males are significantly longer than females of the same age, starting from the second year (1-year old: $t=1.500, \mathrm{df}=183, \mathrm{P}=0.135$; 2-year old: $t=3.272, \mathrm{df}=191$, $\mathrm{P}=0.002$; from 3-year old onwards: always $\mathrm{P}<0.0001$ ).

\section{DISCUSSION}

Length-frequency data have been used mostly for the management of exploited marine and freshwater fish and aquatic invertebrate stocks (Pauly and Morgan, 1987; Rosenberg and Beddington, 1988; Fournier et al., 1998) or for the monitoring strategies of invasive alien species (Anastácio and Marques, 1995; Fidalgo et al., 2001; Chiesa et al., 2006). In this study we showed that modalprogression analysis is a useful approach as a source for obtaining basic information necessary to assess population structure of species of conservation interest (Bjorndal et al., 1995; Salvidio and Delaugerre, 2003; Brusconi et al., 2008). Indeed, conservation and reintroduction strategies ideally require characterization of donor populations regarding growth curves and size and age at sexual maturity (Grandjean et al., 1997a). Size-frequency distribu-

Tab. 2. Features of the population structure for each stream.

\begin{tabular}{|c|c|c|c|c|c|c|c|}
\hline Stream & $\mathbf{N}$ & M & F & Sex ratio & $\begin{array}{l}\text { CPUE } \\
\text { (ind } \cdot \mathrm{min}^{-1} \text { expert }{ }^{-1} \text { ) }\end{array}$ & $\begin{array}{l}\text { Density } \\
\left(\text { ind } \cdot \mathrm{m}^{-2} \text { ) }\right.\end{array}$ & $\begin{array}{c}\text { Biomass } \\
\left(\mathrm{g} \cdot \mathrm{m}^{-2}\right)\end{array}$ \\
\hline Des & 225 & 92 & 133 & $0.69^{*}$ & 1.37 & 4.48 & 29.08 \\
\hline Droanello & 342 & 171 & 171 & 1 & 0.65 & 0.72 & 4.39 \\
\hline Giongo & 106 & 54 & 52 & 1.04 & 0.45 & 0.91 & 7.75 \\
\hline Freddo & 73 & 35 & 38 & 0.92 & 0.71 & 2.1 & 9.15 \\
\hline
\end{tabular}

$N$, sample size; $M$, males; F, females; $C P U E$, catch per unit effort; ${ }^{*}$ Significant difference $(P<0.05)$ from the expected 1:1. 
tions and estimates of growth parameters are known to be potentially affected by the selectivity of the sampling gear used to collect the animals (Montgomery et al., 2010). In order to avoid this bias, we chose to adopt hand sampling by experienced researchers, which is one of the less-selective capture methods for large crayfish (Peay, 2004), and allowed us to obtain a large data set collected within a very short time (only few hours) at night, when crayfish activity was similar in size class, temperatures and sexes (Barbaresi and Gherardi, 2001). The YOY $\left(0^{+}\right.$class $)$did not occur in the frequency distributions since hatching took place some weeks before sampling and the independent juveniles were still too small to be captured (Bernardo et al., 1997) or were still adopting an elusive behavior, which made them difficult to find (Brusconi et al., 2008).
To date, no other study on A. pallipes complex populations' structure and growth had been previously performed in the Alpine biogeographic region. Our data confirmed that the studied populations kept a well-structured age-class composition, achieving up to six classes both for males and females in DES stream. The only exception was the FRE population, which had only three classes in both sexes. A possible explanation might be the extreme environmental conditions of that stream. Indeed, the very low and almost intermittent flow (Tab. 1) could not be suitable to sustain regular population dynamics. It is interesting to note that this is the stream with the earliest estimated hatching date, maybe because shallow streams warm up more quickly than those with greater base-flow, but they are also more at risk of drying out. Our findings

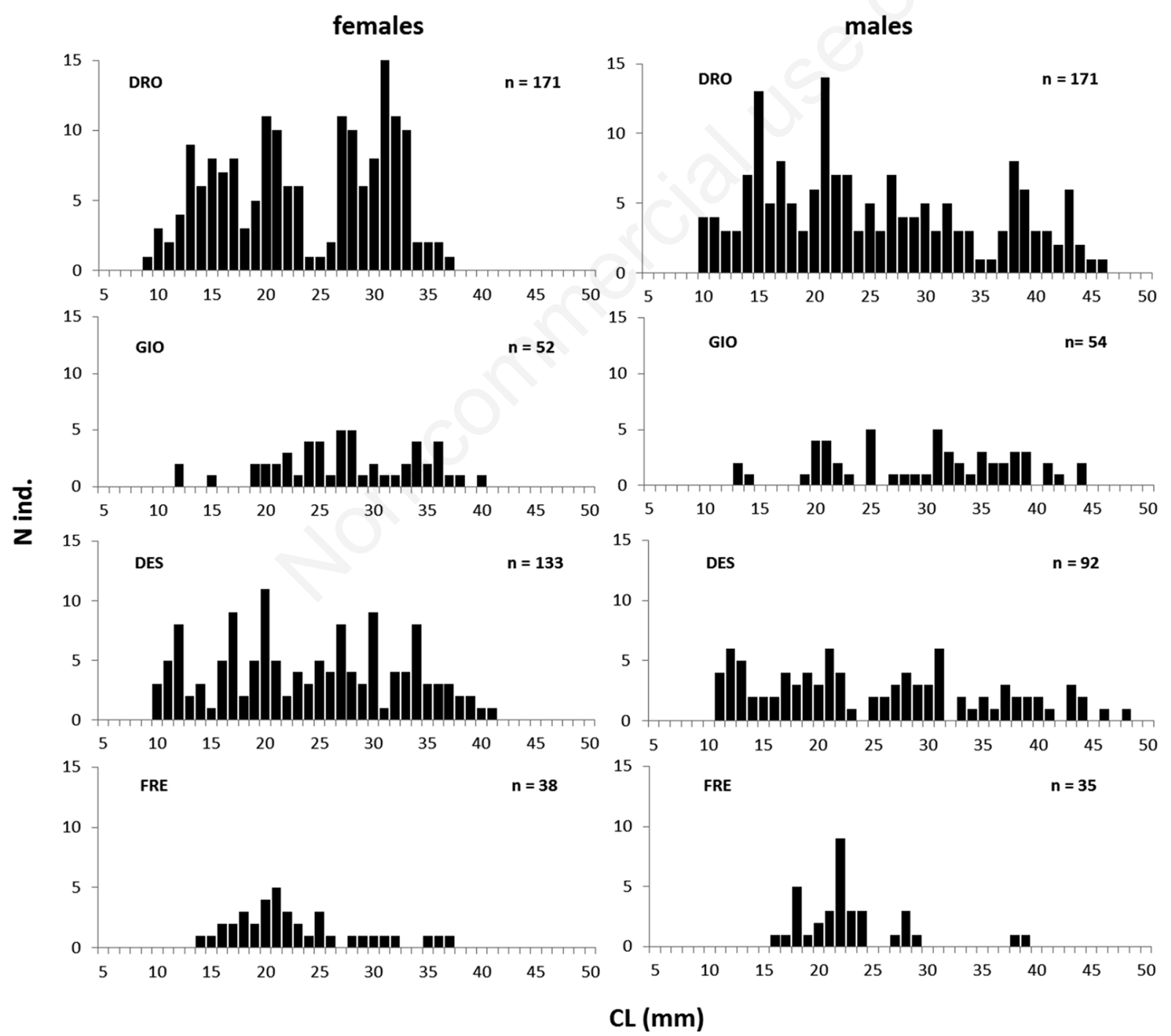

Fig. 3. Length-frequency histograms of females (on the left) and males (on the right), obtained using 1 mm CL intervals (CL, cephalothorax length). 
are in line with Scalici et al. (2008) who obtained up to seven classes for males in Latium streams and with Brusconi et al. (2008) who found five classes for females in Tuscany watercourses. Growth parameters confirmed that A. pallipes complex is a $K$-selected species, with a slow growth rate and a very long life expectancy, showing that both sexes did not grow in winter. Studies on A. pallipes complex populations in other European districts showed statistical differences in growth rate due to latitude (Scalici et al., 2008). Indeed our findings are more consistent with A. pallipes populations in England (Pratten, 1980) than those in central Italy (Scalici et al., 2008). Curvature parameters found for males and females, 0.16 and 0.19 respectively, are the lowest hitherto recorded for the species. The principal factor governing growth rates appears to be temperature (Lowery, 1988). Growth is limited to the period when water temperature exceeded $10^{\circ} \mathrm{C}$ (Pratten, 1980). Indeed our streams recorded on average 187 days with water temperature $>10^{\circ} \mathrm{C}$ (mean $14.2^{\circ} \mathrm{C}$ ) compared to the 192 ones (mean $16.2^{\circ} \mathrm{C}$ ) recalculated from Pratten (1980) who worked on a southern English population. Therefore our findings pointed out the Alpine climatic zone as altitudinal limit for this species.

To date, no other study is comparable to our, because water temperature values were not logged systematically, as we did in our study. Several studies (see Hartnoll, 1982) indicated that seasonal oscillation in growth of crayfish is correlated to seasonal variation in water temperature. This trend of seasonal variation in growth is well expressed by the $C$ values obtained for both sexes, which reach the maximum $(C=1$, i.e., no growth in winter and maximum rate of growth in summer). The almost null growth rate coincides with the November-March period, when temperature remains below $9^{\circ} \mathrm{C}$, and the winter point occurs in the month of January. Growth rate is highest during the

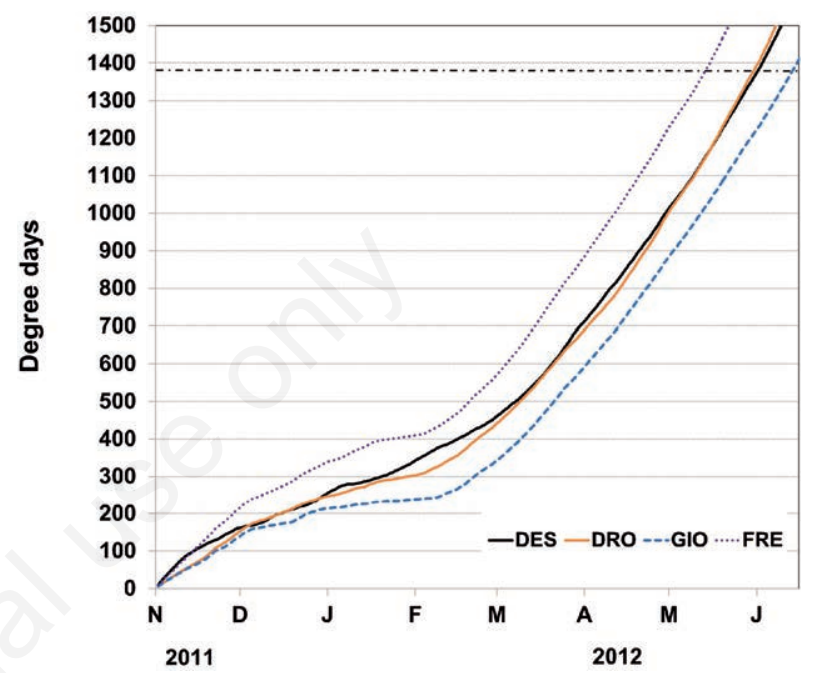

Fig. 4. Cumulative degree days during egg-bearing period in the study streams. Dot-dashed line shows the threshold of total degree-days required to hatching.

Tab. 3. Means and standard deviation of the cephalothorax length, and Separation Index for each age class obtained by the application of the Bhattacharya method.

\begin{tabular}{|c|c|c|c|c|c|c|c|}
\hline \multirow[t]{2}{*}{ Stream } & \multirow[t]{2}{*}{ Age (months) } & \multicolumn{3}{|c|}{ Males } & \multicolumn{3}{|c|}{ Females } \\
\hline & & $N$ & $\operatorname{MCL}(\mathrm{SD})$ & SI & $N$ & MCL (SD) & SI \\
\hline \multirow[t]{6}{*}{ Des } & 13 & 19.4 & $12.5(1.23)$ & - & 16.2 & $11.75(0.73)$ & - \\
\hline & 25 & 14.9 & $21.15(0.98)$ & 3.01 & 41.6 & $18.85(1.87)$ & 2.72 \\
\hline & 37 & 19.9 & $31.5(1.2)$ & 2.74 & 29.3 & $26.31(1.86)$ & 2.36 \\
\hline & 49 & 3.2 & $35.29(0.57)$ & 2.12 & 10.2 & $29.99(0.46)$ & 2.1 \\
\hline & 61 & 6.7 & $39.5(1.2)$ & 2.14 & 16.2 & $33.92(0.77)$ & 2.18 \\
\hline & 73 & 6.3 & $42.5(1.59)$ & 2.01 & 10.9 & $36.1(1.4)$ & 2.04 \\
\hline \multirow[t]{6}{*}{ Droanello } & 13 & 30.2 & $14.69(1.05)$ & - & 50.1 & $14.78(2.12)$ & - \\
\hline & 25 & 29.2 & $21.05(0.81)$ & 2.57 & 37.4 & $21.03(1.35)$ & 2.33 \\
\hline & 37 & 16.1 & $27.09(0.77)$ & 2.41 & 30.5 & $27.83(0.95)$ & 2.4 \\
\hline & 49 & 12.7 & $32(0.99)$ & 2.23 & 48.3 & $31.56(1.19)$ & 2.11 \\
\hline & 61 & 22.4 & $38.41(1.23)$ & 2.25 & 5.8 & $35.68(1.09)$ & 2.11 \\
\hline & 73 & 10.4 & $43.01(0.67)$ & 2.14 & - & - & - \\
\hline \multirow[t]{5}{*}{ Giongo } & 24.5 & 12.6 & $21(1.2)$ & - & 6.6 & $21.77(0.82)$ & \\
\hline & 36.5 & 5.0 & $25.05(0.64)$ & 2.2 & 10.3 & $24.52(0.84)$ & 2.1 \\
\hline & 48.5 & 9.5 & $31.26(0.69)$ & 2.38 & 12.4 & $27.51(0.78)$ & 2.11 \\
\hline & 60.5 & 6.5 & $35.23(0.81)$ & 2.15 & 10.2 & $33.83(1.2)$ & 2.31 \\
\hline & 72.5 & 10.6 & $38.51(1.3)$ & 2.07 & - & - & - \\
\hline \multirow[t]{3}{*}{ Freddo } & 13.5 & 7.4 & $18(0.56)$ & - & 6.6 & $16.5(1.2)$ & - \\
\hline & 25.5 & 15.8 & $22(0.67)$ & 2.3 & 15.4 & $20.78(1.22)$ & 2.21 \\
\hline & 37.5 & 5.3 & $28(0.67)$ & 2.41 & 5.1 & $25.04(0.65)$ & 2.22 \\
\hline
\end{tabular}

$\mathrm{N}$, theoretical number of the crayfish; MCL, means of cephalothorax length; SI, Separation Index. 
summer period. The summer point (i.e., maximum rate of growth) occurs in July, when the average water temperature is $16^{\circ} \mathrm{C}$, the optimum for the species (Arrignon, 1996). This is also the period when also adult females moult, after releasing their young (Lowery, 1988), which occurs in June in the Alpine biogeographic region. Values of the growth performance index for both sexes agreed again with Pratten (1980) and also with Scalici et al. (2008), even though they measured the carapace length from the ocular hollow instead from the tip of the rostrum. The index was slightly higher in females than males, as reported by other previous studies (Pratten, 1980; Brewis and Bowler, 1982; Hogger, 1984; Brusconi et al., 2008). Differences between sexes in CL started from the second year, whereas the smallest reproductive female, showing whitened tissue on the abdominal somites (Reynolds, 2002), measured $27 \mathrm{~mm}$ in CL, hence corresponding to a three years old individual. These results suggested that sexual dimorphism starts before the attainment of sexual maturity, as previously hypothesized by Grandjean et al. (1997b). Accordingly, Brewis and Bowler (1982) also reported that sexual maturity in A. pallipes in Northumbria (Great Britain) is attained when the carapace length is 22$27 \mathrm{~mm}$, but the size matches to the fifth to sixth year of life. It is very likely that maturity is related to size rather than age in A. pallipes; the earlier maturity results from higher growth rates in the warmer waters (Brewis and Bowler, 1982).
Nonetheless, the analyses of size-frequency distributions provide a useful method for estimating age structure of populations of long-lived species, especially when the recruitment season is well defined (Hartnoll, 2001). Alternatives proposed for estimating the age of crustaceans (see Vogt, 2012) include the use of stable isotope ratios in calcareous skeletons (Le Foll et al., 1989), the concentration of lipofuscin pigments in the brain (Sheehy, 1990;

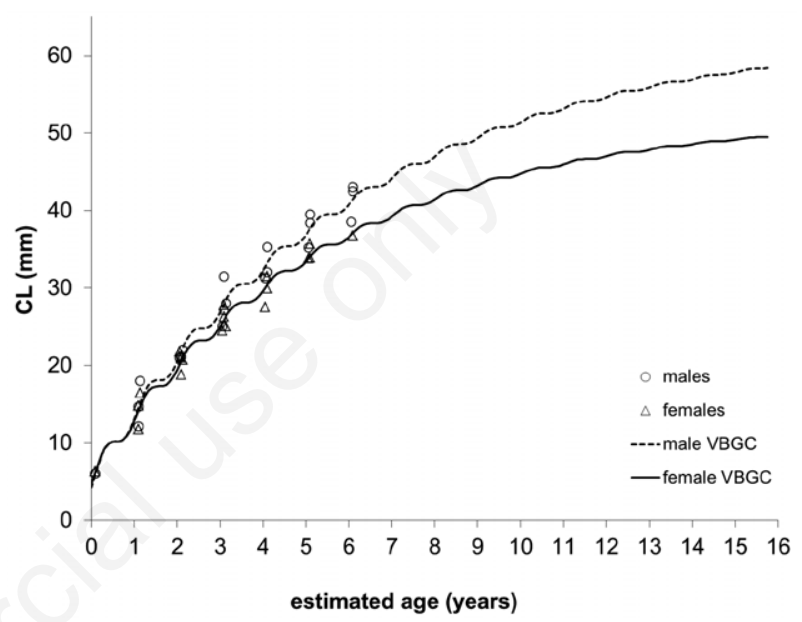

Fig. 5. Seasonalized growth curves for females $(\Delta)$ and males (O), (CL, cephalothorax length).

Tab. 4. Von Bertalanffy's parameters for A. pallipes complex males and females.

\begin{tabular}{lcccccccccccc} 
& $k$ & $C L_{\infty}$ & $t_{0}$ & $t_{\max }$ & $C$ & $t_{w}$ & $r^{2}$ & $\varphi^{\prime}$ & $Z^{\prime}$ & $M$ & \\
Males & 0.16 & 63.01 & -0.67 & 17.85 & 1 & 0.58 & 0.98 & 2.8 & 0.39 & 0.27 & 0.12 \\
Females & 0.19 & 52.00 & -0.73 & 15.06 & 1 & 0.58 & 0.98 & 2.7 & 0.48 & 0.32 & 0.16 \\
\hline
\end{tabular}

$\mathrm{k}$, curvature parameter; $\mathrm{CL}_{\infty}$, mean length of old individuals; $\mathrm{t}_{0}$, initial condition parameter; $\mathrm{t}_{\max }$, expected longevity estimate; $\mathrm{C}$, amplitude; $\mathrm{t}_{\mathrm{w}}$, winter point; $\varphi^{\prime}$, growth performance index; $\mathrm{Z}$, total mortality; $\mathrm{M}$ natural mortality; $\mathrm{F}$, mortality due to poaching.

Tab. 5. Growth parameters of $A$. pallipes species complex (see also Fig. 1). $k$ and $C L_{\infty}$ were obtained from Scalici et al. (2008); $\varphi$ ' values have been computed using $\varphi^{\prime}=\log k+2 \log C L_{\infty}$.

\begin{tabular}{|c|c|c|c|c|c|}
\hline References & Country & Sex & $k$ & $C L_{\infty}(\mathrm{mm})$ & $\varphi^{\prime}$ \\
\hline Pratten (1980) & England & $\begin{array}{l}\mathrm{F} \\
\mathrm{M}\end{array}$ & $\begin{array}{l}0.26 \\
0.21\end{array}$ & $\begin{array}{l}45.60 \\
54.20\end{array}$ & $\begin{array}{l}2.73 \\
2.79\end{array}$ \\
\hline Brewis and Bowler (1982) & England & $\begin{array}{l}\mathrm{F} \\
\mathrm{M}\end{array}$ & $\begin{array}{l}0.31 \\
0.28 \\
\end{array}$ & $\begin{array}{l}47.34 \\
52.11 \\
\end{array}$ & $\begin{array}{l}2.84 \\
2.88 \\
\end{array}$ \\
\hline Hogger (1984) & England & $\begin{array}{l}\mathrm{F} \\
\mathrm{M}\end{array}$ & $\begin{array}{l}0.25 \\
0.23\end{array}$ & $\begin{array}{l}51.44 \\
55.12\end{array}$ & $\begin{array}{l}2.82 \\
2.84\end{array}$ \\
\hline Scalici et al. $(2008)^{*}$ & Italy & $\begin{array}{l}\mathrm{F} \\
\mathrm{M}\end{array}$ & $\begin{array}{l}0.41 \\
0.35 \\
\end{array}$ & $\begin{array}{l}39.03 \\
42.40\end{array}$ & $\begin{array}{l}2.80 \\
2.80\end{array}$ \\
\hline Brusconi et al. (2008) & Italy & $\begin{array}{l}\mathrm{F} \\
\mathrm{M}\end{array}$ & $\begin{array}{l}0.37 \\
0.34\end{array}$ & $\begin{array}{l}52.11 \\
57.89\end{array}$ & $\begin{array}{l}3.00 \\
3.06\end{array}$ \\
\hline
\end{tabular}

*Scalici et al. (2008) referred carapace length as from the ocular hollow to the terminal thorax portion. 
Belchier et al., 1998; Bluhm and Brey, 2001; Maxwell et al., 2007) and the structure of the infra-cerebral organ (Bazin, 1970). All these methods require the sacrifice of individuals, which would not be acceptable in an endangered species like $A$. pallipes.

Finally, our findings suggested that mortality in studied populations of $A$. pallipes is mainly due to natural causes ( $M=69 \%$ and $67 \%$ in males and females respectively), and only a portion is due to poaching. This result contrasts with data reported for Tuscany, where illegal fishing is one of the main causes of mortality for the species (Renai et al., 2006). All the studied populations are within European protected sites, Natura 2000. It is encouraging that the designation appears to be effective in protecting white-clawed crayfish in these watercourses and consequently it may be beneficial to improve and increase the ecological network of these special areas for the conservation of threatened species.

\section{CONCLUSIONS}

We highlight the importance of obtained results as new data on Alpine populations of A. pallipes complex, and also the benefits of such non-invasive approach in determining important population characteristics (age and growth rates) in this native species.

The need for long-term monitoring when dealing with endangered species makes our results useful in development of action and conservation plans of this crayfish.

\section{ACKNOWLEDGMENTS}

This study was partially supported by the European Funds through Financial Instrument for the Environment, LIFE+ (Life 08 NAT/IT/000352 - CRAINat) and by ERSAF - Lombardia. We are very grateful to G. De Franceschi, M. Spairani, P. Vezza, M. Abderhalden, G. Comi and E. Galbussera for helping us with the field work. Special thanks are due to S. Peay (University of Leeds) for her helpful suggestions and for linguistic revision. Moreover, we thank two anonymous reviewers for their valuable comments.

\section{REFERENCES}

Anastàcio PM, Marques JC, 1995. Population Biology and Production of the Red Swamp Crayfish Procambarus clarkii (Girard) in the Lower Mondego River Valley, Portugal. J. Crustac. Biol. 15:156-168.

Aquiloni L, Brusconi S, Cecchinelli E, Tricarico E, Mazza G, Paglianti A, Gherardi F, 2010. Biological control of invasive populations of crayfish: the European eel (Anguilla anguilla) as a predator of Procambarus clarkii. Biol. Invasions 12:3817-3824.

Aquiloni L, Martín M, Gherardi F, Diéguez-Uribeondo J, 2011. The North American crayfish Procambarus clarkii is the carrier of the oomycete Aphanomyces astaci in Italy. Biol. Invasions 13:359-367.

Arrignon J, 1996. L'écrevisse et son élevage, III ed. Lavoisier Technique \& Documentation, Paris: 230 pp.

Barbaresi S, Gherardi F, 2001. Daily activity of the white-clawed crayfish, Austropotamobius pallipes (Lereboullet): a comparison between field and laboratory studies. J. Nat. Hist. 35:1861-1871.

Barbour MT, Gerritsen J, Snyder BD, Stribling JB, 1999. Rapid Bioassessment Protocols for Use in Streams and Wadeable Rivers: Periphyton, Benthic Macroinvertebrates and Fish. Second Edition. EPA 841-B-99-002. U.S. Environmental Protection Agency; Office of Water; Washington, D.C.

Bazin F, 1970. Étude comparée de l'organe deutocérébral des macroures reptantia et des anomoures (Crustacés Décapodes). Arch. Zool. exp. gén. 111:245-264.

Belchier M, Edsman L, Sheehy MRJ, Shelton PMJ, 1998. Estimating age and growth in long-lived temperate freshwater crayfish using lipofuscin. Freshw. Biol. 39:439-446.

Berger C, Füreder L, 2013. Linking species conservation management and legal species protection: a case study on stone crayfish. Freshwater Crayfish 19:161-175.

Bernardo JM, Ilhéu M, Costa AM, 1997. Distribution, population structure and conservation of Austropotamobius pallipes in Portugal. Bull. Fr. Peche Piscic. 347:617-624.

Beverton RJH, 1963. Maturation, growth and mortality of Clupeid and Engraulid stocks in relation to fishing. Cons. Perm. Expl. Mer Rapp. et Proc.-Verb. 154:44-67.

Bhattacharya CG, 1967. A simple method of resolution of a distribution into Gaussian components. Biometrics 23:115-135.

Bilgin S, Samsun O, Ozen O, 2009. Seasonal growth and reproduction biology of the Baltic prawn, Palaemon adspersus (Decapoda: Palaemonidae), in the southern Black Sea. J. Mar. Biol. Assoc. U. K. 89:509-519.

Bjorndal KA, Bolten AB, Coan AL Jr, Kleiber P, 1995. Estimation of green turtle (Chelonia mydas) growth rates from length-frequency analysis. Copeia 1995:71-77.

Bluhm BA, Brey T, 2001. Age determination in the Antarctic shrimp Notocrangon antarcticus (Crustacea: Decapoda), using the autofluorescent pigment lipofuscin. Mar. Biol. 138:247-257.

Brewis JM, Bowler K, 1982. The growth of the freshwater crayfish Austropotamobius pallipes in Northumbria. Freshw. Biol. 12:187-200.

Brusconi S, Bertocchi S, Renai B, Scalici M, Souty-Grosset C, Gherardi F, 2008. Conserving indigenous crayfish: stock assessment and habitat requirements in the threatened $\mathrm{Aus}$ tropotamobius italicus. Aquatic Conserv: Mar. Freshw. Ecosyst. 18:1227-1239.

Capinha C, Brotons L, Anastácio P, 2013. Geographical variability in propagule pressure and climatic suitability explain the European distribution of two highly invasive crayfish. J. Biogeogr. 40:548-558.

Chiesa S, Scalici M, Gibertin G, 2006. Occurrence of allochthonous freshwater crayfishes In Latium (Central Italy). Bull. Fr. Peche Piscic. 380-381:883-902.

Diéguez-Uribeondo J, Rueda A, Castien E, Bascones JC, 1997. A plan of restoration in Navarra for the native freshwater crayfish species of Spain, Austropotamobius pallipes. Bull. Fr. Peche Piscic. 347:625-637. 
Dörr AJM, Scalici M, 2013. Revisiting reproduction and population structure and dynamics of Procambarus clarkii eight years after its introduction into Lake Trasimeno (Central Italy). Knowl. Managt. Aquatic Ecosyst. 408:10.

Favaro L, Tirelli T, Pessani D, 2010. The role of water chemistry in the distribution of Austropotamobius pallipes (Crustacea Decapoda Astacidae) in Piedmont (Italy). C. R. Biol. 333:68-75.

Fea G, Nardi PA, Ghia D, Spairani M, Manenti R, Rossi S, Moroni M, Bernini F, 2006. Dati preliminari sulla distribuzione in Lombardia dei gamberi d'acqua dolce autoctoni e alloctoni. Atti Soc. it. Sci. nat. Museo civ. Stor. nat. Milano 147:201-210.

Fidalgo ML, Carvalho AP, Santos P, 2001. Population dynamics of the red swamp crayfish, Procambarus clarkii (Girard, 1852) from the Aveiro region, Portugal (Decapoda, Cambaridae). Crustaceana 74:369-375.

Fournier DA, Hampton J, Sibert JR, 1998. MULTIFAN-CL: a length-based, age-structured model for fisheries stock assessment, with application to South Pacific albacore, Thunnus alalunga. Can. J. Fish. Aquat. Sci. 55:2105-2116.

France R, Holmes J, Lynch A, 1991. Use of size-frequency data to estimate the age composition of crayfish populations. Can. J. Fish. Aquat. Sci. 48:2324-2332.

Füreder L, Gherardi F, Holdich D, Reynolds J, Sibley P, SoutyGrosset C, 2010. Austropotamobius pallipes. In: IUCN 2010 Red List of Threatened Species. Accessed on: 12 November 2014. Available from: http://www.iucnredlist.org/details/ $2430 / 0$

Gayanilo FC, Sparre P, Pauly D, 1996. The FAO ICLARM stock assessment tools (FISAT) user's guide. Computerized Information Series (Fisheries) 8:1-126.

Gherardi F, 2002. Behaviour, p. 258-290. In: D.M. Holdich (ed.), Biology of freshwater crayfish. Blackwell Science.

Gherardi F, Holdich DM, 1999. Crayfish in Europe as alien species. How to make the best of a bad situation? A.A. Balkema, Rotterdam: 299 pp.

Gherardi F, Smietana P, Laurent P, 2002. Interactions between non-indigenous and indigenous crayfish species. Bull. Fr. Peche Piscic. 367:899-907.

Ghia D, Fea G, Bernini F, Nardi PA, 2011. Reproduction experiment on Austropotamobius pallipes complex under controlled conditions: can hybrids be hatched? Knowl. Managt. Aquat. Ecosyst. 401:16.

Grandjean F, Romain D, Avila-Zarza C, Bramard M, SoutyGrosset C, Mocquard JP, 1997b. Morphometry, sexual dimorphism and size at maturity of the white-clawed crayfish Austropotamobius pallipes pallipes (Lereboullet) from a wild French population at Deux-Sèvres (Decapoda, Astacidae). Crustaceana 70:31-44.

Grandjean F, Romain D, Souty-Grosset C, Mocquard JP, 1997a. Size at sexual maturity and morphometric variability in three populations of Austropotamobius pallipes pallipes (Lereboullet, 1858) according to a restocking strategy. Crustaceana 70:454-468.

Hartnoll RG, 1982. Growth, p. 111-196. In: D.E. Bliss and L.G. Abele (eds.), The biology of Crustacea: embryology, morphology, and genetics. Academic Press.

Hartnoll RG, 2001. Growth in Crustacea - twenty years on. Hydrobiologia 449:111-122.
Hogger JB, 1984. A study of aspects of the biology and distribution of freshwater crayfish in the Thames catchment. Ph.D. Thesis, City of London, Polytechnic.

Holdich DM, 2002. Biology of freshwater crayfish. Blackwell, London: 702 pp.

Holdich DM, Reynolds JD, Southy-Grosset C, Sibley PJ, 2009. A review of the ever increasing threat to European crayfish from non-indigenous crayfish species. Knowl. Managt. Aquat. Ecosyst. 11:394-395.

Holdich DM, Rogers WD, 1997. The white-clawed crayfish, Austropotamobius pallipes, in Great Britain and Ireland with particular reference to its conservation in Great Britain. Bull. Fr. Peche Piscic. 347:597-616.

Le Foll D, Brichet E, Reyss JL, Lalou C, 1989. Age determination of the spider crab Maja Squinado and the European lobster Homarus gammarus by ${ }^{228} \mathrm{Th} /{ }^{228} \mathrm{Ra}$ chronology: possible extension to other crustaceans. Can. J. Fish. Aquat. Sci. 46:720-724.

Lowery RS, 1988. Growth, moulting and reproduction, p. 83-113. In: D.M. Holdich, and R.S. Lowery (eds.), Freshwater crayfish: biology, management and exploitation. Croom Helm.

Manenti R, Bonelli M, Scaccini D, Binda A, Zugnoni A, 2014. Austropotamobius pallipes reduction vs. Procambarus clarkii spreading: Management implications. J. Nat. Conserv. 22:586-591.

Maxwell KE, Matthews TR, Sheehy MRJ, Bertelsen RD, Derby CD, 2007. Neurolipofuscin is a measure of age in Panulirus argus, the Caribbean spiny lobster, in Florida. Biol. Bull. 213:55-66.

Mehtälä J, Vuorisalo T, 2007. Conservation policy and the EU Habitats Directive: favourable conservation status as a measure of conservation success. Eur. Env. 17:363-375.

Montgomery SS, Walsh CT, Haddon M, Kesby CL, Johnson DD, 2010. Using length data in the Schnute Model to describe growth in a metapenaeid from waters off Australia. Mar. Freshw. Res. 61:1435-1445.

Moreau J, Bambino C, Pauly D. 1986. Indices of overall fish growth performance of 100 tilapia (Cichlidae) populations, $p$. 201-206. In: L. MacLean, L.B. Dizon and L.U. Hosillos (eds.), The first Asian fisheries forum. Asian Fisheries Society.

Munro JL, Pauly D, 1983. A simple method for comparing the growth of fishes and invertebrates. ICLARM Fishbyte 1:5-6.

Nardi PA, Bernini F, Bo T, Bonardi A, Fea G, Ghia D, Negri A, Razzetti E, Rossi S, Spairani M, 2005. Status of Austropotamobius pallipes complex in the watercourses of the Alessandria province (N-W Italy). Bull. Fr. Peche Piscic. 376-377: 585-598.

Pauly D, 1979. Gill size and temperature as governing factors in fish growth: a generalization of von Bertalanffy's growth formula. Berichte des Instituts für Meereskunde an der Univ. Kiel: 156 pp.

Pauly D, 1980. On the interrelationships between natural mortality, growth parameters and mean environmental temperature in 175 fish stocks. J. Cons. CIEM 39:175-192.

Pauly D, Gaschütz G, 1979. A simple method for fitting oscillating length growth data, with a program for pocket calculators. International Council for the Exploration of the Sea, Council Meeting No. 1979/G:24, Demersal Fish Committee: 26 pp.

Pauly D, Morgan GR, 1987. Length-based methods in fisheries research, ICLARM Conf. Proceeding 13, 468 pp. 
Pauly D, Sorianobartz M, Moreau J, Jarreteichmann A, 1992. A new model accounting for seasonal cessation of growth in fishes. Aust. J. Mar. Freshw. Res. 43:1151-1156.

Peay S, 2004. A cost-led evaluation of survey methods and monitoring for white-clawed crayfish - lessons from the UK. Bull. Fr. Peche Piscic. 372-373:335-352.

Piccoli F, Di Renzo G, Fea G, Fracassi G, Garozzo P, Ghia D, Lanciani G, Marrone M, Porfirio S, Santillo D, Salvatore B, Scoccia M, Nardi Pa, Comini B, Pagliani T, 2012. [Il progetto LIFE+ Natura CRAINat "Conservation and Recovery of Austropotamobius pallipes in Italian Natura2000 sites": primi risultati dello studio di fattibilità].[Article in Italian]. Biologia Ambientale 26:90-95.

Pratten DJ, 1980. Growth in the crayfish Austropotamobius pallipes (Crustacea: Astacidae). Freshwater Biol. 10:401-412.

Quinn II TJ, Deriso RB, 1999. Quantitative fish dynamics. Oxford University Press, New York: 560 p.

Renai B, Bertocchi S, Brusconi S, Gherardi F, Grandjean F, Lebboroni M, Parinet B, Souty-Grosset C, Trouilhe MC, 2006. Ecological characterisation of streams in Tuscany (Italy) for the management of the threatened crayfish Austropotamobius pallipes complex. Bull. Fr. Peche Piscic. 380-381:1095-1113.

Reynolds JD, 2002. Growth and reproduction, p. 152-191. In: D.M. Holdich (ed.), Biology of freshwater crayfish. Blackwell Science.

Rosenberg AA, Beddington JR, 1988. Length-based methods of fish stock assessment, p. 83-103. In: J.A. Gulland (ed.), Fish population dynamics. J. Wiley \& Sons.

Salvidio S, Delaugerre M, 2003. Population dynamics of the European leaf-toed gecko (Euleptes europaea) in NW Italy: implications for conservation. Herpetol. J. 13:81-88.

Scalici M, Belluscio A, Gibertini G, 2008. Understanding population structure and dynamics in threatened crayfish. J. Zool. 275:160-171.
Sheehy MRJ, 1990. Potential of morphological lipofuscin age-pigment as an index of crustacean age. Mar. Biol. 107:439-442.

Smietana P, Krzywosz T, 2006. Determination of the rate of growth of Pacifastacus leniusculus in Lake Pobłędzie, using polymodal length frequency distribution analysis. Bull. Fr. Peche Piscic. 380-381:1229-1243.

Smith GRT, Learner MA, Slater FM, Foster J, 1996. Habitat features important for the conservation of the native crayfish Austropotamobius pallipes in Britain. Biol. Conserv. 75:239-246.

Sokal RR, Rohlf FJ, 1995. Biometry: the principles and practice of statistics in biological research, $3^{\text {rd }}$ ed. W.H. Freeman and Company: 887 pp.

Souty-Grosset C, Holdich DM, Noël PY, Reynolds JD, Haffner P, 2006. Atlas of Crayfish in Europe. Muséum National d'Histoire Naturelle, Paris: 188 pp.

Sparre P, Venema SC, 1996. [Introduction à l'évaluation des stocks de poissons tropicaux. Document technique sur les pêches, 306/1, Rev.1].[Document in French]. FAO, Rome: 410 pp.

Taylor CC, 1962. Growth equation with metabolic parameter. J. Cons. int. Explor. Mer. 23:366-370.

Trouilhe MC, Souty-Grosset C, Grandjean F, Parinet B, 2007. Physical and chemical water requirements of the whiteclawed crayfish (Austropotamobius pallipes) in western France. Aquat. Conserv. 17:520-538.

Vogt G, 2012. Ageing and longevity in the Decapoda (Crustacea): a review. Zool. Anz. 251:1-25.

Von Bertalanffy L, 1938. A quantitative theory of organic growth. Hum. Biol. 10:181-213.

Wetherall JA, 1986. A new method for estimating growth and mortality parameters from length-frequency data. ICLARM Fishbyte 4:12-14.

Whitehouse AT, Peay S, Kindemba V, 2009. Ark sites for whiteclawed crayfish - guidance for the aggregates industry. Buglife - The Invertebrate Conservation Trust: 11 pp. 